\title{
TÁC DỤNG HẠ GLUCOSE MÁU TRÊN THỰC NGHIỆM CỦA VIÊN ANDIABET
}

Nguyễn Thị Huơng Giang, Phan Thị Tố Nhu Truờng Đại học Dược Hà Nội

DOI: $10.47122 / v j d e .2020 .41 .14$

\section{ABSTRACT}

Andiabet is a compound of 3 herbal medicines: Lagerstroemia speciosa (L.)Pers; Gynostemma pentaphyllum (Thunb.) Makino; Anemarrhenae Aspheloides (Bunge) usedfor treating type 2 diabetes mellitus. Objective: to investigate theantidiabetic effect of Andiabet. Method: The antidiabetic effect of Andiabet was evaluated inSTZ-induced diabetic mice. Result: Andiabet at 0,$76 ; 0,87 ;$ and $2,29 \mathrm{~g} / \mathrm{kg} /$ day doses orally for 14days improved the glucose homeostasis and lipid metabolism. The blood glucose levelssignificant decreased about $36 \%$ comparable to the nontreated diabetic mice group. Conclusion: This study investigated the antidiabetic of Andiabet in experiment.

Key words: Lagerstroemia speciosa (L.)Pers, Gynostemma pentaphyllum (Thunb.) Makino, Anemarrhenae Aspheloides (Bunge), type 2 diabetes mellitus

\section{TÓM TẮT}

Viên nang cứng Andiabet là sự kết hợp của 3 loại thảo dược: Bằng lăng nước, Giảo cổ lam và Tri mẫu, bào chế theo tỷ lệ 1,5:1,5:1 được sử dụng hỗ trợ trong điều trị đái tháo đường (ĐТĐ). Muc tiêu: Đánh giá tác dụng hạ glucose máu của viên thuốc Andiabet. Phuơng pháp nghiên cứu: Nghiên cứu tác dụng hạ glucose máu (HGM) và hạ lipid máu của Andiabet trên chuột nhắt trắng gây ĐTĐ typ 2. Kết quả: Andiabet cả 3 liều: 0,$68 ; 1$ và 2 $\mathrm{g} / \mathrm{kg} / \mathrm{ngày}$ sau 2 tuần liên tục uống đã gây HGM trên chuột nhắt ĐTĐ typ 2, đồng thời làm giảm $\mathrm{LDL}-\mathrm{C}$ và tăng $\mathrm{HDL}-\mathrm{C}$. Andiabet $2 \mathrm{~g} / \mathrm{kg} /$ ngày làm giảm Cholesterol toàn phần và triglyceride. Kết luận: Andiabet có tác dụng tốt trong điều trị ĐTĐ typ 2 trên thực nghiệm.

Tù khóa: Bằng lăng nước, ĐTĐ typ 2, Giảo cổ lam, Tri mẫu.
Chịu trách nhiệm chính: Nguyễn Thị Hương Giang

Ngày nhận bài: $8 / 8 / 2020$

Ngày phản biện khoa học: 9/9/2020

Ngày duyệt bài: 13/10/2020

Email: ng.t.huong.giang@gmail.com

\section{1. ĐẠTT VẤN ĐỀ}

Đái tháo đường (ĐTĐ)typ 2 là bệnh rối loạn chuyển hóa có cơ chế phức tạp, rất khó khăn khi điều trị với liệu pháp đơn trị liệu. Do đó, liệu pháp kết hợp trở thành một lựa chọn thay thế trên lâm sàng, bởi vì việc kết hợp các thuốc có thể làm tăng khả năng hạ glucose máu (HGM)do tác động trên nhiều đích tác dụng khác nhau, bổ sung, nâng cao hiệu quả điều trị của thuốc, đồng thời làm giảm liều dùng, giảm tác dụng phụ. Bằng Lăng nước (BLN), Giảo Cổ Lam (GCL)và Tri Mẫu (TM) là các dược liệu đã được chứng minh riêng rẽ về hiệu quả trị bệnh ĐTĐ qua nhiều nghiên cứu tiền lâm sàng và lâm sàng [1],[2],[3],[4],[5]. Với mong muốn tạo ra một sản phẩm có tác dụng điều trị ĐTĐ hiệu quả, chúng tôi nghiên cứu kết hợp 3 thành phần này trong chế phẩm Andiabet và để đánh giá hiệu quả của sự kết hợp này, đề tài "Nghiên cứu tác dụng hạ glucose máu của viên Andiabet trên thực nghiệm" được tiến hành với 2 mục tiêu:

1. Đánh giá tác dụng ha glucose máu của viên Andiabet trên chuột nhắt trắng gây ĐTÐ kiểu typ 2.

2. Đánh giá tác dụng ha lipid máu của viên Andiabet trên chuột nhắt trắng gây ĐTĐ kiểu typ 2.

\section{2. ĐỐI TƯợNG VÀ PHƯƠNG PHÁP NGHIÊN CÚU}

2.1. Chế phẩm nghiên cứu:

Thuốc thử Andiabet dạng viên nang cứng 
gồm 3 vị: Giảo Cổ Lam, Bằng Lăng Nước và Tri Mẫu được bào chế theo tỷ lệ1,5:1,5:1. Trọng lượng 01 viên nang là $590 \mathrm{mg}$.

\subsection{Hoá chất và dụng cụ nghiên cúu:}

Streptozotocin (STZ) lọ $1 \mathrm{~g}$ của hãng Sigma-Aldrich (Singapore). Diamicron (gliclazid) viên nang 30mg, hãng Servier (Pháp). Máy đo đường huyết và kit định lượngglucose On Call Plus của hãng ACON Biotech (Mỹ). Bộ kit đo triglycerid, HDL-C, cholesterol huyết thanh của hãng DIALAB $\mathrm{GmbH}$ (Áo). Máy sinh hóa bán tự động XC55 của hãng Chemistry Analyzer (Trung Quốc). Dung dịch đệm Citrat pH 4.5. Các hoá chất xét nghiệm và làm tiêu bản mô bệnh học.

\section{3. Động vật nghiên cứu:}

Chuột nhằt trắng chủng Swiss, giống đực, trọng lượng $25 \pm 2 \mathrm{~g}$, do viện Vệ sinh dịch tễ Trung ương cung cấp. Chuột được nuôi trong điều kiện phòng thí nghiệm 5 ngày trước khi tiến hành nghiên cứu.

\subsection{Phương pháp nghiên cứu}

Nghiên cúu tác dụng ha glucose máu của viên Andiabet trên chuột ĐTĐ typ 2.

Gây mô hình ĐTĐ kiểu typ 2 theo phương pháp Fabiola và Srinivasan [6].

Lô thí nghiệm: Chuột được chia thành 6 lô, mỗi lô 10 con.

Lô 1: Lô chứngsinh học: chế độ NFD + uống nước cất

Lô 2: Lô chứng bệnh: Chế độ HFD + tiêm STZ liều $100 \mathrm{mg} / \mathrm{kg}+$ uống nước cất

Lô 3: Chế độ HFD + tiêm STZ liều $100 \mathrm{mg} / \mathrm{kg}$ + uống gliclazid liều $80 \mathrm{mg} / \mathrm{kg}$

Lô 4: Chế độ HFD + tiêm STZ liều $100 \mathrm{mg} / \mathrm{kg}+$ uống Andiabetliều $0,68 \mathrm{~g} / \mathrm{kg} / \mathrm{ng}$

Lô 5: Chế độ HFD + tiêm STZ liều $100 \mathrm{mg} / \mathrm{kg}+$ uống Andiabetliều $1 \mathrm{~g} / \mathrm{kg} / \mathrm{ng}$

Lô 6: Chế độ HFD + tiêm STZ liều $100 \mathrm{mg} / \mathrm{kg}+$ uống Andiabetliều $2 \mathrm{~g} / \mathrm{kg} / \mathrm{ng}$
Tiến hành: Tất cả chuột ở 6 lô được lấy máu đuôi, định lượng glucose máu lần $1 \mathrm{khi}$ bắt đầu tham gia nghiên cứu (nhịn đói qua đêm). Chuột lô 1 được nuôi bằng chế độ ăn bình thường (NFD-normal fat diet), các lô từ 2 đến 6 được nuôi bằng chế độ ăn giàu chất béo (HFD-high fat diet) trong 8 tuần liên tục. Sau 8 tuẩn, tất cả chuột được lấy máu đuôi, định lượng glucose máu lần 2 (nhịn đói qua đêm).

Tiêm STZ liều $100 \mathrm{mg} / \mathrm{kg}$ cho các lô chuột từ 2 đến 6 , lô 1 tiêm dung dịch đệm citrat $\mathrm{pH}$ 4.5 là dung môi pha STZ. 72 giờ sau tiêm STZ hoặc dung dịch đệm, định lượng glucose máu lần 3 , chọn các chuột ở lô tiêm STZ bị ĐTĐ (mức glucose lúc đói $>10 \mathrm{mmol} / \mathrm{l}$ ) được tham gia nghiên cứu.

Đánh giá tác dụng HGM của thuốc:Chuột lô 1 và 2 được uống nước cất liên tụctrong 2 tuần.Chuột lô 3 đến 6 uống thuốc thử liên tục trong 2 tuần.Định lượng Glucose máu tại các thời điểm $\mathrm{t}_{\mathrm{o}}$ (trước uống thuốc thử), $\mathrm{t}_{1}$ (sau uống thuốc thử 1 tuần) và $\mathrm{t}_{2}$ (sau uống thuốc thử 2 tuần). Định lượng các chỉ số lipid máu (cholesterol, triglycerid, HDL-C và LDL-C) tại thời điểm $\mathrm{t}_{2}$.

Đồng thời mổ chuột lấy gan, tụy để đánh giá cân nặng, quan sát hình ảnh đại thể vàvi thể ngẫu nhiên $30 \%$ số chuột mỗi lô. Các xét nghiệm vi thể được thực hiện tại Trung tâm Nghiên cứu và phát hiện sớm Ung thư.

\subsection{Phương pháp xử lý số liệu:}

Dữ liệu được phân tích bằng phần mềm MS. Excel và SPSS22. Các số liệu nghiên cứu được xử lý thống kê theo phương pháp t-test Student, phân tích phương sai ANOVA one way đơn biến và lặp lại.

Số liệu được biểu diễn dưới dạng: $\bar{X} \pm$ $S D$, Sự khác biệt có ý nghĩa khi $\mathrm{p}<0,05$.

\section{KẾT QUẢ NGHIÊN CÚ̉U}

\subsection{Triển khai mô hình gây ĐTĐ typ2.}

Bảng 1. Sự thay đổi trọng lượng chuột tại các thời điểm nghiên cứu

\begin{tabular}{|l|c|c|c|}
\hline \multirow{2}{*}{ Thời gian } & \multicolumn{2}{|c|}{ Trọng lượng (g) } & p so với lô $\mathbf{~}$ \\
\cline { 2 - 4 } & Lô $\mathbf{~ N D F ~}(\mathrm{n}=10)$ & Lô $\mathbf{H D F}(\mathrm{n}=100)$ & \\
\hline Trước nghiên cứu & $25,45 \pm 0,98$ & $26,09 \pm 1,30$ & $>0,05$ \\
\hline
\end{tabular}




\begin{tabular}{|l|c|c|c|}
\hline Sau 4 tuần & $29,60 \pm 1,15 * * *$ & $37,17 \pm 1,89 * * *$ & $<\mathbf{0 , 0 0 1}$ \\
\hline \% tăng & $\uparrow \mathbf{1 6 , 3}$ & $\uparrow \mathbf{4 2 , 5}$ & \\
\hline Sau 6 tuần & $33,60 \pm 1,43 * * *$ & $42,89 \pm 1,93 * * *$ & $<\mathbf{0 , 0 0 1}$ \\
\hline \% tăng & $\uparrow \mathbf{3 2 , 0}$ & $\uparrow \mathbf{6 4 , 4}$ & \\
\hline Sau 8 tuần & $35,90 \pm 1,45 * * *$ & $48,47 \pm 2,27 * * *$ & $<\mathbf{0 , 0 0 1}$ \\
\hline \% tăng & $\uparrow \mathbf{4 1 , 1}$ & $\uparrow \mathbf{8 5 , 8}$ & \\
\hline
\end{tabular}

Nhận xét: Trọng lượng của chuột ở lô HDF (chế độ ăn $40 \%$ năng lượng là lipid $+55 \%$ fructose) sau 4 tuần, 6 tuần và 8 tuần đều tăng rõ rệt so với lô chứng cùng thời điểm, sự khác biệt có ý nghĩa thống kê $(p<0,01)$.

Bảng 2. Biến đổi nồng độ glucose máuchuột sau chế độ ăn 8 tuần giàu chất béo.

\begin{tabular}{|l|c|c|c|}
\hline \multirow{2}{*}{ Thời gian } & \multicolumn{2}{|c|}{ Glucose máu (mmol/l) $(\mathbf{X} \pm \overline{\mathbf{S} D})$} & P so với lô 1 \\
\cline { 2 - 4 } & Lô $\mathbf{~ N D F}(\mathrm{n}=10)$ & Lô $\mathbf{H D F}(\mathrm{n}=100)$ & \\
\hline Trước nghiên cứu & $5,37 \pm 0,56$ & $5,56 \pm 1,02$ & $>0,05$ \\
\hline Sau 8 tuần & $5,77 \pm 0,67$ & $6,32 \pm 0,93$ & $>0,05$ \\
\hline \% thay đổi & $\uparrow 7,4$ & $\uparrow \mathbf{1 3 , 7}$ & \\
\hline Sau tiêm STZ 72 & $5,98 \pm 0,92$ & $17,09 \pm 6,33 * * *$ & $<\mathbf{0 , 0 0 1}$ \\
\hline \% thay đổi & $\uparrow \mathbf{1 1 , 4}$ & $\uparrow 207,4$ & \\
\hline
\end{tabular}

***: $p<0,001:$ p so với trước tiêm STZ.

Nhận xét: Sau khi ăn thức ăn giàu chất béo 8 tuần nồng độ glucose máu của chuột ở lô 2 có xu hướng tăng so với nồng độ glucose máu của chuột nhóm chứng trắng, nhưng sự khác biệt chưa có ý nghĩa thống kê $(\mathrm{p}>0,05)$. Sau 72 giờ tiêm $\mathrm{STZ}$, nồng độ glucose máu ở lô 2 đã tăng cao rõ rệt so với lô chứng $(\mathrm{p}<0,001)$ và so với thời điểm trước khi tiêm $\mathrm{STZ}(\mathrm{p}<0,001)$.

\subsection{Tác dụng hạ glucose máu của Andiabet trên chuột nhắt gây ĐTĐ typ 2.}

Bảng 3. Ảnh hưởng của Andiabet lên nồng độ glucose máucủa chuột ĐTĐ typ 2

\begin{tabular}{|c|c|c|c|}
\hline \multirow{2}{*}{ Lô chuột $(n=10)$} & \multicolumn{3}{|c|}{ Nồng độ glucose máu mmol/l (X } \\
\hline & $\mathbf{T}_{\mathbf{0}}$ & $\mathbf{T}_{1}$ & $\mathbf{T}_{2}$ \\
\hline Lô 1: Chứng sinh học. Nước cất & $5,54 \pm 0,86$ & $5,51 \pm 0,81$ & $5,46 \pm 0,46$ \\
\hline Lô 2:Chứng bệnh: ĐTĐ + Nước cất & $17,88 \pm 6,23$ & $18,38 \pm 4,46$ & $18,38 \pm 4,39$ \\
\hline Lô 3: Chuột ĐTĐ. Gliclazid 80mg/kg & $17,36 \pm 5,26$ & $14,18 \pm 5,23 *$ & $13,83 \pm 3,45 * *$ \\
\hline \% giảm so lô chứng bệnh & & $\downarrow 22,9 \%$ & $\downarrow 24,8 \%$ \\
\hline Lô 4:ĐTĐ+ Andiabet0,68 g/kg/ng & $17,89 \pm 6,3$ & $13,99 \pm 3,61 *$ & $16,71 \pm 4,46$ \\
\hline \% giảm so lô chứng bệnh & & $\downarrow 23,9 \%$ & $\downarrow 9,1 \%$ \\
\hline Lô 5: ĐТĐ + Andiabet1 g/kg/ng & $19,23 \pm 6,3$ & $18,78 \pm 3,61$ & $11,83 \pm 3,91 * *$ \\
\hline \% giảm so lô chứng bệnh & & $\downarrow 4,6 \%$ & $\downarrow 35,6 \%$ \\
\hline Lô 6: ĐТĐ + Andiabet2 g/kg/ng & $18,04 \pm 5,27$ & $11,69 \pm 3,78 * *$ & $14,84 \pm 5,01 *$ \\
\hline \% giảm so lô chứng bệnh & & $\downarrow 36,4 \%$ & $\downarrow 19,3 \%$ \\
\hline
\end{tabular}

$p$ so với lô chứng: *: $p<0,05 ; * *: p<0,01 ; * * *: p<0,001$.

Nhận xét: Sau 1 tuần uống thuốc thử, Andiabet liều $0,68 \mathrm{~g} / \mathrm{kg} / \mathrm{ngày} \mathrm{và} \mathrm{liều} 2 \mathrm{~g} / \mathrm{kg} / \mathrm{ngày} \mathrm{đã}$ làm HGM so với lô chứng bệnh gây ĐTĐ, mức hạ lần lượt là $23,9 \%$ và $36,4 \%$, sự khác biệt có ý nghĩa thống kê với $\mathrm{p}<0,05$ và $\mathrm{p}<0,01$.

Sau 2 tuần uống thuốc thử Andiabet liều $1 \mathrm{~g} / \mathrm{kg} /$ ngày đã làm HGM rõ so với lô chứng bệnh, mức hạ tới 35,6\% ( $\mathrm{p}<0,01)$. 


\subsection{Tác dụng hạ lipid máu của Andiabet trên chuột nhắt trắng ĐTĐ typ 2.}

Bảng 4. Ảnh hưởng của Andiabet lên nồng độ lipid máu chuột nhắt ĐTĐ typ 2.

\begin{tabular}{|c|c|c|c|c|}
\hline \multirow{2}{*}{ Lô chuột $(n=10)$} & \multicolumn{4}{|c|}{ Nồng độ lipid máu mmol/l ( $\overline{\mathrm{X} \pm \mathrm{SD}})$} \\
\hline & TC & TG & HDL-C & LDL-C \\
\hline $\begin{array}{l}\text { Lô 1: Chuột bình thường. } \\
\text { Nước cất. }\end{array}$ & $2,75 \pm 0,55$ & $0,50 \pm 0,17$ & $1,40 \pm 0,11$ & $1,12 \pm 0,40$ \\
\hline $\begin{array}{l}\text { Lô 2: Chuột ĐTĐ. } \\
\text { Nước cất. }\end{array}$ & $3,85 \pm 0,56$ & $0,89 \pm 0,28$ & $1,79 \pm 0,22$ & $1,64 \pm 0,47$ \\
\hline $\begin{array}{l}\text { Lô 3: Chuột ĐTĐ } \\
\text { Gliclazid 80mg/kg }\end{array}$ & $3,86 \pm 0,52$ & $0,81 \pm 0,18$ & $1,89 \pm 0,31$ & $1,60 \pm 0,63$ \\
\hline $\begin{array}{l}\text { Lô 4: Chuột ĐTĐ. } \\
\text { Andiabet } 0,68 \mathrm{~g} / \mathrm{kg} / \mathrm{ngày}\end{array}$ & $3,70 \pm 0,61$ & $0,81 \pm 0,22$ & $2 \pm 0,21 * * *$ & $1,05 \pm 0,66^{* *}$ \\
\hline $\begin{array}{l}\text { Lô5: Chuột ĐTĐ. } \\
\text { Andiabet1g/kg/ngày }\end{array}$ & $3,63 \pm 0,38$ & $0,9 \pm 0,13$ & $2,07 \pm 0,16^{* *}$ & $1,15 \pm 0,32 * * *$ \\
\hline $\begin{array}{l}\text { Lô 6: Chuột ĐTĐ. } \\
\text { Andiabet2g/kg/ngày }\end{array}$ & $3,23 \pm 0,50 * *$ & $0,62 \pm 0,16^{* *}$ & $2,15 \pm 0,21 * * *$ & $0,81 \pm 0,43 * * *$ \\
\hline
\end{tabular}

$p$ so lô chúng: *: $p<0,05$; **: $p<$ 0,$01 ; * * *: p<0,001$. Cholesterol toàn phần (TC), triglyceride (TG)

Nhận xét: Andiabet ở tất cả các mức liều, sau khi uống liên tục 2 tuần đã làm hạ nồng độ LDL-Cvà làm tăng nồng độ HDL-C so với lô chứng bệnh, sự khác biệt có ý nghĩa thống kê $(p<0,01$ và $p<0,001)$, mức hạ mạnh hơn so lô uống gliclazid $80 \mathrm{mg} / \mathrm{kg} /$ ngày. Ngoài ra Andiabet liều $2 \mathrm{~g} / \mathrm{kg} /$ ngày uống liên tục trong 2 tuần làm giảm rõ nồng độ $\mathrm{TC}, \mathrm{TG}$ so với lô chứng bệnh $(\mathrm{p}<0,01)$.

3.4. Ảnh hưởng của Andiabet trên trọng lượng gan, tụy chuột và kết quả giải phẫu bệnh của chuột gây ĐTĐ kiểu typ 2.

Trọng luợng gan và tuyy:Ở tất cả các lô uống Andiabet đều có xu hướng giảm so với lô chứng bệnh nhưng sự khác biệt chưa có ý nghĩa thống kê ( $\mathrm{p}>0,05)$

Quan sát đại thế:

Gan: Lô chứng (NFD + nước cất) có màu hồng sẫm, đồng đều về màu sắc. Mật độ mô chắc và đồng đều. Các lô tiêm STZ đều có màu sắc bạc, kém đều màu hơn và mật độ mô có phần lỏng lẻo so với lô chứng sinh học.

Tuy: Ở tất cả các lô đều có màu hồng nhạt, mật độ dai và chắc. Không xung huyết, không thấy tổn thương đại thể.

Quan sát vi thế:
Gan: Ở các lô uống Andiabet: $2 / 3$ mẫu bệnh phẩm có tình trạng thoái hóa mỡ nhẹ: bào tương các tế bào gan có ít các hốc sáng nhỏ.1/3 mẫu bệnh phẩm có tình trạng thoái hóa mỡ vừa: bào tương các tế bào gan có các hốc sáng không đều, tế bào gan tăng kích thước, được so sánh với lô chứng bệnh, 100\% mẫu bệnh phẩm có tình trạng thoái hóa mỡ nặng: tế bào gan sưng phồng, có các hốc sáng to, bào tương sáng, một số tế bào mất nhân, có nhiều ổ tế bào thoái hóa mỡ.

Tuyy: ở các lô uống Andiabet, 100\% mẫu bệnh phẩm tụy có hiện tượng thoái hóa. Các tế bảo đảo tụy, tiểu đảo tụy giảm nhẹ về kích thước, mật độ tiểu đảo ít hơn so với bình thường được so sánh với lô mô hình $100 \%$ mẫu bệnh phẩm tụy bị thoái hóa: mật độ tiểu đảo tụy giảm. Đảo tụy biến dạng, giảm về kích thước, tế bào tiểu đảo tụy thoái hóa, teo lại.

\section{BÀN LUẬN \\ 4.1. Tác dụng HGM của viên Andiabet trên chuột nhắt gây ĐTĐ kiểu typ2. \\ Trên chuột nhắt gây ĐTĐ kiểu typ 2, sau 2 tuần liên tục uống thuốc thử, Andiabet có tác dụng HGM tối đa $\sim 36 \%$ so với lô chứng bệnh, sự khác biệt có ý nghĩa thống kê với $\mathrm{p}<0.01$ (bảng 3). Mức HGM này tương đương mức HGM của GCL liều $1000 \mathrm{mg} / \mathrm{kg} /$ ngày trong}


nghiên cứu của Đào Văn Phan[3], tuy nhiên hàm lượng GCL trong viên Andiabet chỉ ở mức 291,2mg.

Trong nghiên cứu của Phùng Thanh Hương, dịch chiết lá BLN liều $10 \mathrm{~g} / \mathrm{kg} /$ ngày, cho chuột cống ĐTĐ typ 2 uống liên tục trong 20 ngày đã làm HGM 20 \%[2]. Còn Hong $\mathrm{H}$ cho biết dịch chiết lá BLN chứa $1 \%$ acid corosolic, sau khi cho chuột nhắt ĐTĐ typ 2 tự phát chủng C57BLKsJ uống trong 4 tuần đã làm HGM $26 \%$ [5]. Hàm lượng BLN trong viên Andiabet cũng tương đương như GCL là $291,2 \mathrm{mg}$. Như vậy dạng kết hợp có tác dụng HGM cao hơn và liều thấp hơn so với dùng riêng rẽ từng dược liệu. Nguyễn Trọng Thông nghiên cứu Vinabetes (gồm GCL+ BLN+TM) trên chuột cống trắng gây ĐTĐ kiểu typ 2 , liều $3 \mathrm{~g} / \mathrm{kg} /$ ngày trong 2 tuần, cho kết quả nồng độ glucose máu giảm $44 \%[4]$.

Vinabetes có cùng công thức kết hợp, nhưng lại có tác dụng HGM mạnh hơn Andiabet có thể do: (1) liều cao hơn: Vinabetes liều $3 \mathrm{~g} / \mathrm{kg} /$ ngày trên chuột cống trắng tương đương liều $6 \mathrm{~g} / \mathrm{kg} /$ ngày trên chuột nhắt trắng, tức là gấp 7-8 lần liều dùng trên lâm sàng của Andiabet. (2) dạng bào chế khác: Vinabetes là dạng cao nước bào chế trong phòng thí nghiệm, còn Andiabet là dạng viên nang cứng bào chế theo quy trình công nghiệp; (3) đáp ứng trên chuột cống khác với đáp ứng trên chuột nhắt.

4.2. Tác dụng hạ lipid máu của Andiabet trên chuột nhắt ĐTĐ kiểu typ 2.

Nghiên cứu này cũng nhận thấy Andiabet có tác dụng hạ lipid máu tốt, tất cả các lô uống Andiabet đều làm giảm nồng độ LDL-C và làm tăng nồng độ HDL-C rõ so với lô chứng bệnh, sự khác biệt có ý nghĩa thống kê $(\mathrm{p}<0,01$ và $\mathrm{p}<0,001)$, trong khi đó $B L N$ dùng riêng rẽ[2] hay Vinabetes [4] đều chưa thể hiện được tác dụng hạ lipid máu trên chuột gây ĐTĐ kiểu typ 2.

Tác dụng tốt trên nồng độ glucose máu và nồng độ lipid máu của viên Andiabet cũng được thể hiện chân thực qua hình ảnh đại thể và vi thể gan, tụy của các lô chuột uống Andiabet. Tình trạng thoái hóa của các tế bào gan, tiểu đảo tụy đều được cải thiện so với lô chứng bệnh.

\section{KẾT LUẬN}

Trên chuột gây ĐTĐ kiểu typ2: Andiabet ở cả 3 mức liều: $0,68 \mathrm{~g} / \mathrm{kg} /$ ngày; $1 \mathrm{~g} / \mathrm{kg} /$ ngày và $2 \mathrm{~g} / \mathrm{kg} /$ ngày sau 2 tuần uống liên tục có tác dụng HGM tối đa tới $35,6 \%$ so với lô chứng bệnh $(\mathrm{p}<0.01)$ và đã làm giảm nồng độ $\mathrm{TC}$, TG, LDL-C và tăng nồng độ HDL-C rõ so với lô chứng bệnh, sự khác biệt có ý nghĩa thống kê $(p<0,01$ và $p<0,001)$. Đồng thời sau khi uống liên tục trong 2 tuần, Andiabet ở cả 3 mức liều đều có tác dụng cải thiện hình ảnh đại thể và cấu trúc vi thể gan và tụy của chuột được gây mô hình bệnh ĐTĐ kiểu typ 2 .

\section{TÀI LIỆ THAM KHẢO}

1. Phạm Hữu Điển, Nguyễn Khánh Hòa và Đào Văn Phan (2003), "Nghiên cứu khả năng hạ đường huyết của tri mẫu và mangiferin chiết tách từ tri mẫu", Tap chi hóa sinh hoc. 3(6), tr. 83-88.

2. Phùng Thanh Hương và Nguyễn Thị Thu Hiền (2009), "Tác dụng của dịch chiết lá Bằng lăng nước (Lagerstroemia speciosa (L.) Pers.) trên chuột cống đái tháo đường typ 2", Tap chí Dược hoc. số 401 năm 49(9/2009), tr. 19.

3. Đào Văn Phan, Nguyễn Khánh Hoà và Nguyễn Duy Thuần (2003), "Nghiên cứu sàng lọc tác dụng hạ đường huyết của sinh địa, móng trâu, thất diệp đởm và tri mẫu", Tạp chí nghiên cúu Y hoc, Bộ Y tế, Đại học Y Hà Nội. 21(1), tr. 1-6. .

4. Nguyễn Trọng Thông, Phạm Thị Vân Anh và CS (2011), "Nghiên cứu tác dụng hạ glucose huyết của Vinabetes trên thực nghiệm", Tạp chi dược học, tr. 38-41.

5. Hong H (2004), "Effects of malted barley extract and bababa extract on blood glucose level in genetically diabetic mice", Journal of Medical Food. 7(4), tr. 487-489.

6. Srinivasan K., Viswanad $B$ và et al (2005), "Combination of high fat diet-fed and low-dose streptozotocin-treated rat: A model for type 2 diabetes and pharmacologycal screening", Pharmacological research. 52(4), tr. 313-320. 